\title{
High Capture Threshold
}

National Cancer Institute

\section{Source}

National Cancer Institute. High Capture Threshold. NCI Thesaurus. Code C95875.

Problem with the amount of output energy needed to cause cardiac depolarization being higher than expected/desired. 